\title{
Materiały kolekcyjne owsa w Krajowym Centrum Roślinnych Zasobów Genowych
}

\author{
Oat collection of the National Centre for Plant Genetic Resources
}

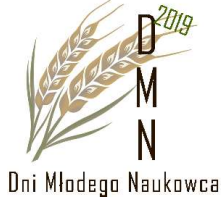

Dorota Dziubińska $\bowtie$, Wiesław Podyma

Instytut Hodowli i Aklimatyzacji Roślin - Państwowy Instytut Badawczy, Radzików,

Krajowe Centrum Roślinnych Zasobów Genowych,

$\triangle$ e-mail: d.dziubinska@ihar.edu.pl

\begin{abstract}
Owies jest jednym z najważniejszych zbóż uprawianych na świecie. Ziarno owsa znajduje zastosowanie w produkcji żywności, pasz oraz w przemyśle. W celu zachowania różnorodności gatunków owsa w Krajowym Centrum Roślinnych Zasobów Genowych powstała kolekcja obejmująca zarówno uprawne jak i dzikie jego formy. Zadaniem kolekcji jest zarówno gromadzenie jak również ocena i charakterystyka zebranych obiektów.
\end{abstract}

Słowa kluczowe: owies, zasoby genowe

Oats are among the most important cereals grown in the world. Oat grains are used in the production of food, animal feed and in industry. In order to conserve the diversity of oat species, a collection including both cultivated and wild forms was established at the National Centre for Plant Genetic Resources. The main task of the collection is also the collection and evaluation of collected accessions.

Key words: oat, gene resourses

Owies jest jednym $\mathrm{z}$ najważniejszych zbóż uprawnych na świecie. Owies zwyczajny (Avena sativa L.) jest wartościowym elementem w żywieniu człowieka, produkcji pasz oraz przemyśle (1). Ziarno owsa zawiera duże ilości białka, tłuszcz bogaty w nienasycone kwasy tłuszczowe oraz wiele innych substancji wpływających korzystnie na funkcjonowanie organizmu $\mathrm{m}$. in. związki o właściwościach antyoksydacyjnych (1). Natomiast dzikie gatunki z rodzaju Avena stanowią bogatą pulę różnorodności genetycznej dla owsa zwyczajnego, która może być wykorzystana w programach hodowlanych jako źródło pożądanych genów (2).

Kolekcja owsa zgromadzona w przechowalni długoterminowej Krajowego Centrum Roślinnych Zasobow Genowych (KCRZG) Instytutu Hodowli i Aklimatyzacji Roślin-Państwowego Instytutu Badawczego (IHAR-PIB) w Radzikowie liczy 2641 obiektów z rodzaju Avena, z czego 2241 czyli $84 \%$ kolekcji stanowią obiekty przypisane do gatunku owies zwyczajny - Avena sativa L. W kolekcji znajdują się również gatunki uprawne: Avena byzantina C. Koch., A. strigosa Schreb., A. abyssinica Hochst. oraz dzikie: $A$. gadiriana B. R. Baum \& G. Fedak, A. atlantica Baum et
Fedak, A. barbata Pott ex Link, A. canariensis B. R. Baum, A. damascene Rajhathy \& Baum, $A$. fatua L., A. hirtula Lag., A. insularis Ladiz., A. longiglumis Durieu., A. macrostachya Balansa \& Durieu, A. magna Murphy \& Terrel, A. murphyi Ladiz., A. occidentalis Durieu., A. pilosa Aucher ex Durieu, $A$. sterilis L., A. ventricosa Balansa, $A$. wiestii Steud. (Rys.1).

Są to gatunki pochodzące z 53 krajów na całym świecie. Najwięcej obiektów pochodzi z różnych regionów Polski, Stanów Zjednoczonych oraz krajów europejskich takich jak Niemcy, Szwecja, Holandia czy Wielka Brytania, jednakże w kolekcji znajdują się również obiekty z Ameryki Łacińskiej oraz Chin (Rys. 2).

Prace w kolekcji owsa realizowane są od roku 1972 i mają one na celu pozyskiwanie, udostępnianie oraz utrzymanie obiektów owsa w stanie żywym w warunkach ex situ, charakterystykę i ocenę obiektów dla hodowli, badań naukowych i działalności szkoleniowej oraz prowadzenie dokumentacji.

We współpracy $\mathrm{z}$ przechowalnią długoterminową prowadzona jest coroczna regeneracja obiektów uprawnych oraz gatunków dzikich. Jednocześnie na sześciu poletkach w IHAR - PIB 


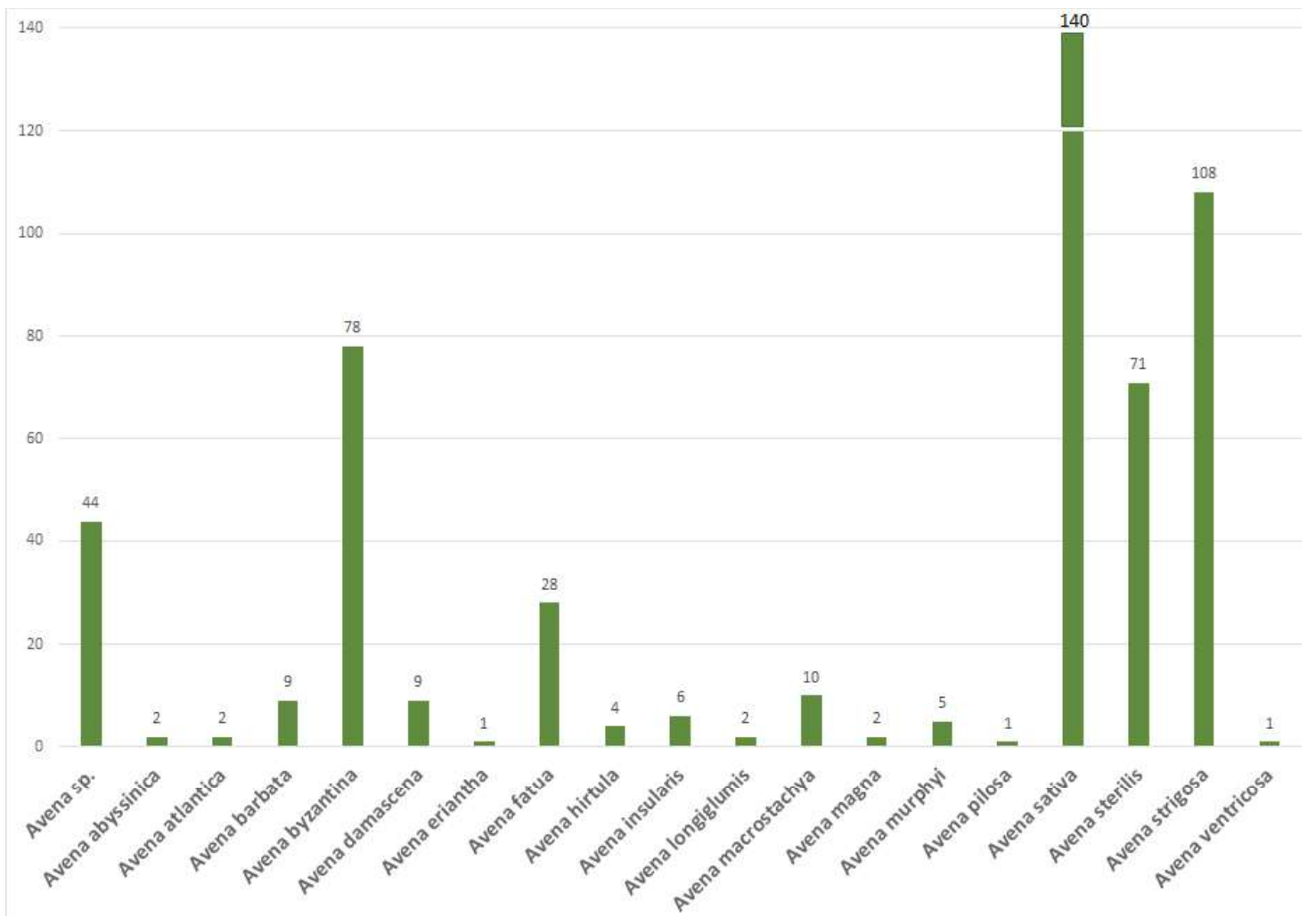

Rys. 1. Liczba obiektów poszczególnych gatunków owsa Fig. 1. Number of accessions of oat species

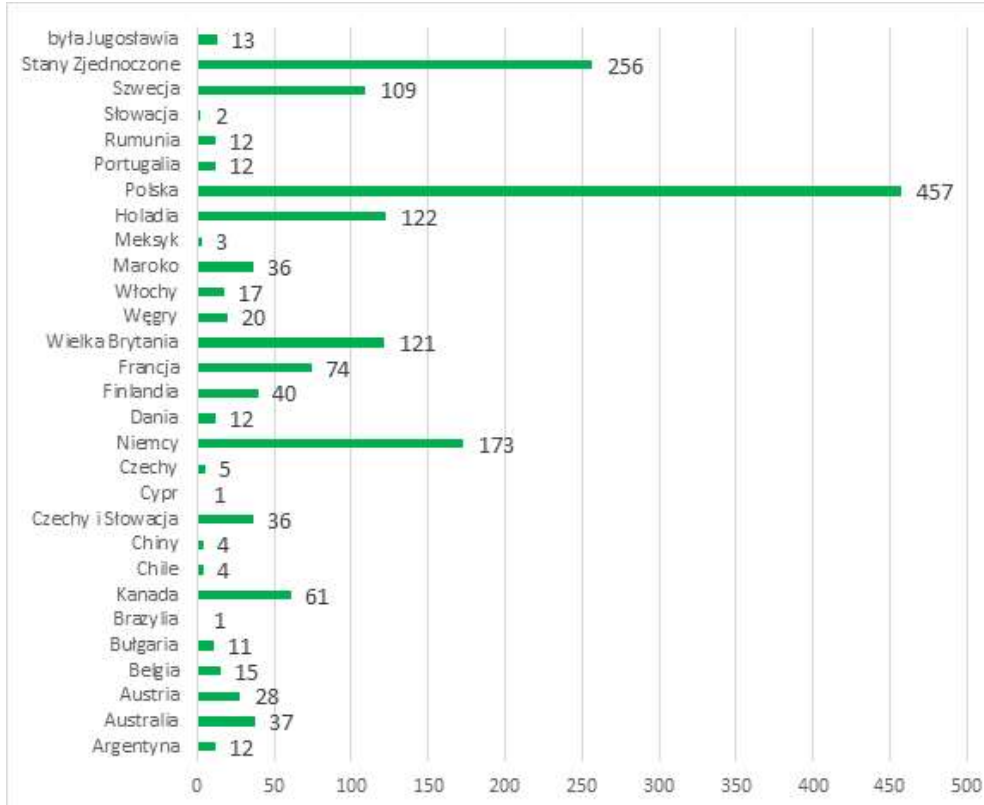

Rys. 1. Liczba obiektów pozyskanych z poszczególnych krajów Fig. 2. Number of accessions according to the country of origin 
Radzików oraz czterech w Ogrodzie Botanicznym PAN w Powsinie regenerowane są obiekty wieloletniego, zimotrwałego gatunku Avena macrostachya. Obecnie Krajowe Centrum Roślinnych Zasobów Genowych posiada największą jego kolekcję na świecie. W celu uzupełniania danych oceny oraz charakterystyki zakładane są trzyletnie doświadczenia ewaluacyjne. Obecnie do doświadczenia zostało właczonych 20 polskich starych odmian, 20 lokalnych oraz 15 odmian nagich i 15 o czarnej łusce. Podczas sezonu wegetacyjnego ocenia się wybrane cechy morfologiczne, rolnicze oraz technologiczne: określana jest data wschodów, wiechowanie, gotowości do zbioru, typ i kształt wiechy, wysokość roślin, długość wiechy oraz odporność na porażenie chorobami (rdzą koronową i źdźbłową, mączniakiem prawdziwym, septoriozą, BYDV i innymi), a także wyleganie w dwóch terminach. Po zbiorze nasion oraz ich oczyszczeniu, określany jest plon, masa tysiąca ziaren i kolor plewki. Opis przeprowadzony jest zgodnie z listą deskryptorów IPGRI (3) i metodyką Centralnego Ośrodka Badania Odmian Roślin Uprawnych (COBORU). Prowadzona jest również dokumentacja fotograficzna zarówno obiektów regenerowanych jak i włączonych do doświadczenia, a kolekcja jest sukcesywnie wzbogacana poprzez wprowadzanie do niej nowych obiektów pozyskiwanych z zagranicznych banków genów lub podczas ekspedycji. Obecne 332 obiekty posiadają dokumentację fotograficzną, która jest dostępna na stronie internetowej: wyszukiwarka.ihar.edu.pl .

Kolekcja owsa Krajowego Centrum Roślinnych Zasobów Genowych jest warunkiem zachowania różnorodności gatunkowej roślin i stwarza możliwość zachowania unikatowych okazów wielu rzadkich gatunków. Jest także wykorzystywana jako źródło materiałów do badań naukowych i hodowli. Obiekty z kolekcji owsa w tym dziki gatunek A. macrostachya zostały wykorzystane w IHAR PIB w hodowli owsa ozimego dla warunków klimatycznych Polski.

\section{Literatura}

Bartnikowska, E., Lange, E., Rakowska, M. (2000) Ziarno owsa - niedoceniane źródło składników odżywczych i biologicznie czynnych. Część II. Polisacharydy i włókno pokarmowe, składniki mineralne, witaminy. Biul. IHAR 215: 223-237.

Loscutov, I. G. (2008). On evolutionary pathways of Avena species. Genet Res. Crop Evol. 55: 211-220.

IBPGR Rome (1985). International board for plant genetic resouces oat descriptors

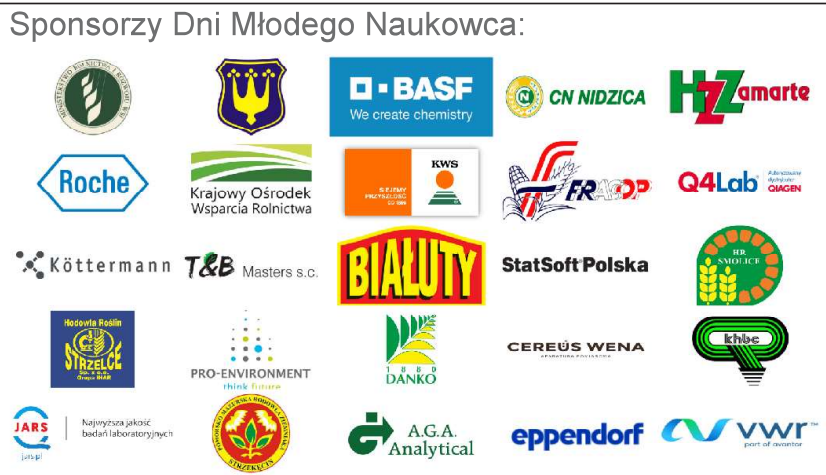


